\title{
STRATEGI MENINGKATKAN KEMAMPUAN PUSTAKAWAN DALAM MELAYANI PEMUSTAKA DI PERPUSTAKAAN INSTITUT AGAMA ISLAM NEGERI PONTIANAK
}

\author{
Melda Mitania, Sahidi \\ Program Studi Diploma 3 perpustakaan FKIP Untan Pontianak \\ Email: Meldamitania@untan.com
}

\begin{abstract}
This study discusses strategies to improve the ability of librarians in serving users at the IAIN Pontianak Library. The purpose of the study was to determine the library strategy of IAIN Pontianak to improve the ability of librarians to serve users, types of services and library constraints in implementing strategies to improve the ability of librarians. This type of research is descriptive research with a qualitative approach. The data sources of this research are the head of the library, librarians, and users. Data collection techniques through observation, interviews, and documentation. The results showed that the strategy carried out by the IAIN Pontianak library was to include librarians and library staff in librarianship training, become members of librarian organizations at both the provincial and national librarianship organizations and improve literacy education. The types of services provided by librarians to users are the behavior of librarians towards users to improve services, types of services that are not yet available, types of services that are most influential and how to deal with users who complain about services. The obstacles faced are the basic abilities of various librarians, limited funds, and the librarians have not mastered the basic applications of information systems.
\end{abstract}

Keywords: Library, Strategy, type of service

\section{PENDAHULUAN}

Di Dalam rancangan Undang - Undang (RUU) Perpustakaan pada Bab 1 Pasal 1 Menyatakan bahwa, "Perpustakaan adalah sebuah institusi yg mengumpulkan pengetahuan tercetak \& terekam, mengelola menggunakan cara spesifik buat memenuhi kebutuhan intelektualitas para pengguna melalui banyak sekali cara hubungan pengetahuan." (Darmanto, 2020). Perpustakaan adalah suatu lembaga tertentu yang secara teratur menyimpan koleksi dan bahan pustaka, mengelolanya secara khusus sebagai sumber informasi, dan tersedia bagi pembaca dan pengguna. Perpustakaan tidak boleh dipahami sebagai bangunan tempat menyimpan buku-buku atau sebagai tempat penampungan fisik. Secara sederhana, perpustakaan adalah suatu kesatuan kerja dngan sumber daya manusia, kumpulan kolesi menurut jenis perpustakaan.

Perpustakaan universitas merupakan perpustakaan yang berada di suatu lembaga pendidikan tinggi seperti universitas atau lembaga pendidikan tinggi lainnya. Perpustakaan akademik berkewajiban memenuhi kebutuhan informasi pengguna civitas akademika yaitu mahasiswa dan dosen. Akibatnya, banyak perpustakaan menawarkan layanan kepada pengguna non pendidikan (Hermawan, 2006). Perpustakaan perguruan tinggi melayani pemakai kalangan civitas akademika di perguruan tinggi yang bersangkutan, seperti mahasiswa, para dosen, dan karyawanya. 
Perpustakaan perguruan tinggi wajib bisa memenuhi kebutuhan warta lingkungan perguruan tinggi, menunjang kurikulum, aplikasi Tri Dharma Perguruan Tinggi, penelitian \& aktivitas akademis lainnya. (Rahayu, 2011). Berdasarkan lingkungan universitas masih beranggapan bahwa perpustakaan perguruan tinggi dimana buku dan bahan cetak lainnya disimpan dan dipinjamkan, oleh karena itu, nilai sebuah universitas atau lembaga penelitian dan akademik tergantung pada kualitas, integritas, dan integritas layanan perpustakaan. Pustakawan adalah sumber daya yang menggerakkan sumber daya lain dalam organisasi perpustakaan yang memungkinkan perpustakaan dapat berperan secara optimal di dalam melaksanakan tugas pokok dan fungsinya, sehingga pustakawan menjadi ujung tombak keberhasilan dalam penyebarluasan informasi di perpustakaan. (Suwarno, 2017) Lingkungan kerja perpustakaan tidak terkecuali, dan pustakawan, salah satu promotor kehidupan perpustakaan, bekerja pada persyaratan etika untuk menciptakan kerjasama yang harmonis dan lingkungan kerja yang bermanfaat.

Menurut Filippo dalam Lasa (2017) menyebutkan bahwa manajemen SDM/Manajemen SDM merencanakan, mengatur, mengontrol, dan memantau kegiatan pengadaan, pengembangan, penghargaan, integritas, pemeliharaan, dan pelepasan sumber daya manusia untuk mencapai tujuan individu, organisasi, dan koletif yang berbeda. Dari pengertian tersebut bahwa ada semacam "Pengakuan" bahwa sumber daya manusia merupakan unsur utama dalam pencapaian tujuan tujuan lembaga, organisasi dan perpustakaan. SDM merupakan peran penting didalam lembaga (perpustakaan). Perkembangan teknologi informasi memang sangat membantu kinerja perpustakaan, namun keberadaan sumber daya manusia tidak dapat diabaikan dalam menentukan keberhasilan suatu perpustakaan. Sebab sumber daya manusia merupakan sumber daya yang dapat menggerakkan sumber daya lain dan dapat dikembangkan. Perpustakaan sebagai jasa layanan informasi harus berorientasi pada kepuasan pemustaka. Untuk itu, petugas perpustakaan perlu memiliki pengetahuan, keterampilan, sikap, dan perilaku tentang karakteristik pemustaka. Kebutuhan dan keinginan pemustaka merupakan fokus dari sebuah perencanaan, pelaksanaan, dan evaluasi kegiatan perpustakaan. Seluruh staf perpustakaan harus mampu berperan aktif dalam pengembangan perpustakaan.

Layanan perpustakaan adalah peran penting yang harus diperhatikan oleh perpustakaan, secara dinamis berkembang seiring dengan kebutuhan dan pemahaman masyarakat terhadap informasi. Karena sebuah perpustakaan baik buruk didalam layanan yang diberikan oleh pustakawan kepada pemustaka. Pada dasarnya tujuan didalam penyelenggaraan layanan diperpustakaan untuk memaksimalkan pemanfaatan bahan pustaka untuk memenuhi kebutuhan informasi pemakai. Jadi menurut (Rahayu lisda, 2011) setiap jenis perpustakaan memiliki tujuan yang berbeda. Berbagai jenis kegiatan layanan perpustakaan dilakukan untuk mendukung tujuan yang ingin dicapai dan sasaran yang berbeda maka untuk menunjang tujuan yang ingin dicapai.

Perpustakaan IAIN Pontianak adalah perpustakaan yang menyediakan informasi bagi Mahasiswa/Mahasiswi yang ada di perpustakaa IAIN Pontianak, perpustakaan ini di bawah naungan Perguruan Tinggi. Tujuan utama penyelenggaraan perpustakaan ini untuk memperlancar fungsi 
perguruan tinggi (pendidikan, penelitian, pengabdian pada masyarakat).

(Rulyah, 2018) profesi pustakawan melakuan tugasnya yaitu berbasis dalam kecakapan khusus yang dimilikinya. Kecakapan merupakan proses pada pendidikan training yang terus-menerus, sebagai akibatnya mengakibatkan pustakawan mempunyai kompetensi. Hanya mereka yang memiliki keterampilan khusus yang dapat menjadikannya sebuah profesi. Profesionalisme pustakawan mempunyai arti pelaksanaan kegiatan perpustakaan yang didasarkan pada keahlian dan rasa tanggung jawab sebagai pengelola perpustakaan. Keahlian menjadi faktor tertentu dalam menghasilkan hasil kerja serta memecahkan masalah yang mungkin muncul. Akibatnya, pustakawan memiliki banyak tugas dan tugas sebagai staf perpustakaan. Oleh karena itu, pustakawan perlu memanfaatkan pelatihan dan pendidikan lanjutan yang berkelanjutan sesuai dengan Pasal 33 No. 43 Tahun 2007 untuk mencapai hasil yang optimal.

\section{METODE PENELITIAN}

Metode penelitian ini menggunakan metode penelitian kualitatif deskriptif dengan teknik pengumpulan data, berupa kegiatan observasi, wawancara, dan dokumentasi. Adapun narasumber dalam penelitian ini merupakan kepala perpustakaan, staf perpustakaan dan pemustaka Institut Agama Islam Negeri Pontianak.

\section{HASIL PENELITIAN DAN PEMBAHASAN}

Hasil

sumber daya manusia (SDM) merupakan unsur utama pada pencapaian tujuan - tujuan lembaga, organisasi dan perpustakaan. SDM memiliki peran penting dalam suatu lembaga (perpustakaan).
Perkembangan teknologi informasi memang sangat membantu kinerja perpustakaan, namun keberadaan sumber daya manusia tidak dapat diabaikan dalam menentukan keberhasilan suatu perpustakaan. Sebab sumber daya manusia merupakan sumber daya yang dapat menggerakkan sumber daya lain dan dapat dikembangkan. Perpustakaan sebagai jasa layanan informasi harus berorientasi pada kepuasan pemustaka. Untuk itu, petugas perpustakaan perlu memiliki pengetahuan, keterampilan, sikap, dan perilaku tentang karakteristik pemustaka. Kebutuhan dan keinginan pemustaka merupakan fokus dasi semua perencanaan, pelaksanaan dan evaluasi kegiatan perpustakaan. Pengguna adalah fokus dari semua perencanaan, pelaksanaan dan evaluasi kegiatan perpustakaan. Seluruh personel perpustakaan harus mampu berperan aktif dalam pengembangan perpustakaan.

Layanan perpustakaan harus diperhatikan dan dikembangkan secara dinamis oleh perpustakaan berdasarkan kebutuhan dan pemahaman masyarakat akan informasi. Perpustakaan dapat dianggap baik atau buruk berdasarkan layanan yang diberikan pustakawan kepada pengguna. Pada dasarnya tujuan diselenggarakannya layanan perpustakaan adalah untuk memaksimalkan pengguna bahan pustaka di perpustakaan dan memenuhi kebutuhan informasi pengguna.

Salah satu strategi yang dilakukan oleh perpustakaan IAIN Pontianak merupakan untuk meningkatkan sumber daya manusia dengan merekrut pegawai yang mempunyai ijazah IP (ilmu perpustakaan). Mengikuti pemerintah tentang persyaratan inpassing dalam jabatan fungsional pustakawan. Mengikutsertakan pegawai/staff yang ada di perpustakaan IAIN pendidikan dan program automasi dan 
TI. Mengikut sertakan dan mengajukan untuk mengikuti seminar dalam bidang pustakawan. sumber daya manusia yang ada di Perpustakaan IAIN seluruh staf berjumlah 13 orang, pegawai/kontrak 3 orang, pustakawan 3 orang, pegawai yang mempunyai ijazah pustakawan 6 orang, pegawai yang tidak mempunyai ijazah 7 orang.

Berdasarkan pengamatan penulis sistem pelayanan yang dilakukan oleh Perpustakaan IAIN Pontianak pada layanan sirkulasi dan referensi bahwa kemampuan pustakawan Perpustakaan IAIN Pontianak masih belum optimal karena petugas Perpustakaan IAIN Pontianak masih belum bisa menerapkan teori profesional pustakawan, salah satu alasanya karena petugas yang melayani pemustaka bukan dari pendidikan IP (Ilmu Perpustakaan). Untuk menciptakan layanan prima maka perpustakaan IAIN harus menyediakan tenaga perpustakaan yang profesional dalam memberikan layanan pada pemustaka. Agar petugas perpustakaan IAIN Pontianak memberikan layanan sesuai dengan teori untuk meningkatkan loyalitas pemustaka.

\section{Pembahasan}

Berdasarkan hasil penelitian dilakukan oleh penulis, strategi meningkatkan kemampuan pustakawan dalam melayani pemustaka dapat diuraikan sebagai berikut.

1. Mengikutsertakan pustakawan pada diklat kepustakawanan.

Melalui pelatihan dan diklat kepustakawanan, diharapkan pustakawan dapat meningkatkan kompetensi pustakawan dan mewujudkan produktivitas kinerja dalam menjalankan tugas kepustakawanan terutama dalam menghasilkan kinerja yang unggulan sesuai kompetensi yang dimilikinya. Oleh karena itu, perlunya pustakawan dan tenaga perpustakaan diikutsertakan dalam kegiatan tersebut agar mendapatkan pengalaman dan mendapatkan SK diklat kepustakawanan. Berdasarkan hasil dari wawancara yang dilakukan (12 Juli 2021) mengatakan bahwa : "untuk mencapai tujuan perpustakaan, tentunya ada beberapa kegiatan sehingga mampu mendukung atau meningkatkan kemampuan itu dari segi pemimpin tentunya mendorong memotivasi dan memberikan kesempatan kepada pustakawan dan tenaga perpustakaan, semua pegawai yang ada di perpustakaan baik yang PNS maupun yang kontrak tanpa membedakan, baik yang mempunyai SK pustakawan atau yang belum mempunyai SK pustakawan. Untuk meningkatkan kompetensi itu antara lain melalui kesempatan mengikuti diklat pendidikan dan pelatihan pendidikan outputnya bukti berupa ijazah atau SK diklat".

Menurut Nurwarniatun (2019) Pengembangan sumber daya manusia yaitu proses yang akan dilakukan dalam meningkatkan wawasan, keahlian, dan kecakapan melalui pendidikan atau pelatihan yang berkelanjutan yang bertujuan untuk memenuhi standar yang di lakukan oleh organisasi.

2. Mengikutsertakan Pustakawan dalam Pelatihan atau Seminar/ Webinar Nasional.

Pelatihan atau ikut berperan aktif dalam seminar nasional merupakan proses untuk membentuk dan membekali ilmu kepada staf perpustakaan dengan menambahkan keahlian, keterampilan, kedisiplinan, dan kebijakan sehingga dengan diikutsertakan pelatihan dapat membentuk perilaku staf perpustakaan sesuai dengan yang diharapkan. Pelatihan diperlukan untuk staff perpustakaan khususnya bagi staf yang 
akan melayani pemustaka yang berkunjung di perpustakaan. Berdasarkan hasil dari wawancara yang dilakukan (12 Juni 2021) beliau mengatakan bahwa : "latihan diklat pendidikan itu output nya berupa sertifikat bagi mereka yang mengikuti pelatihan yang terkait tentang pendidikan pelayanan pemustaka."

Menurut Qurotianti, (2018) mengutip dari Lasa Hs (2017) Pelatihan adalah usaha untuk merencanakan kegiatan dalam meningkatkan pengetahuan, keterampilan, dan kemampuan pada pegawai. Pelatihan yaitu proses pembelajaran untuk diberikan kepada semua pegawai guna meningkatkan keterampilan, kemampuan, dan pengetahuan pada pegawai yang mengikuti pelaksanaan pekerjaan dengan standar instansi.

3. Menjadi anggota pada organisasi pustakawan baik tingkat daerah Provinsi maupun pada Organisasi Kepustakawanan.

Berperan aktif dalam organisasi dapat meningkatkan wawasan pengetahuan yang didapat dalam suatu organisasi merupakan proses mendapatkan keahlian agar pustakawan lebih berkualitas dan mampu menjalankan tugasnya sesuai standar. Berdasarkan hasil dari wawancara yang di lakukan (12 Juni 2021) mengatakan bahwa : "dengan aktif mengikuti organisasi perpustakaan, staf perpustakaan dan pustakawan bisa menjalin kerjasama juga meningkatkan wawasan pengetahuan mereka, bisa saling bertukar pendapat agar informasi terbaru bisa cepat update".

Menurut Hapdari (2011) Salah satu poin agar bisa disebut profesi adalah mempunyai organisasi profesi. Organisasi profesi seperti diamanati dalam UU No. 43 Tahun 2007 adalah sebagai berikut: pustakawan mendirikan organisasi profesi, berperan membentuk dan perlindungan profesional pustakawan untuk pustakawan menjadi anggota profesi, dan organisasi yang dibina, dikembangkan dan di majukan oleh pemerintah, pemerintah daerah, dan/atau masyarakat.

\section{Layanan kepada pemustaka di perpustakaan Institut Agama Islam Negeri Pontianak}

Berdasarkan hasil wawancara yang dilakukan oleh penulis, layanan kepada pemustaka dapat diuraikan sebagai berikut.

1. Perilaku pustakawan terhadap pemustaka dalam meningkatkan layanan.

Sikap yang baik sangat penting dalam berkomunikasi antara pustakawan dan pemustaka dilakukan agar terjalin komunikasi yang baik sehingga pemustaka puas dengan layanan pustakawan berikan. Dalam melayani pustakawan harus menciptakan layanan yang membuat pengguna merasa nyaman dan betah berada di perpustakaan .

Pentingnya strategi layanan yang dilakukan dan diterapkan oleh perpustakaan untuk meningkatkan minat kunjung pemustaka, harus adanya komunikasi dan memberikan arahan dengan pemustaka yang berkunjung di perpustakaan. Dengan begitu untuk memberikan kepuasan pemustaka berkunjung ke perpustakaan maka perlu terus mengembangkan teknologi komunikasi dan informasi. Agar pemustaka puas dengan kualitas pelayanan yang efektif, maka sudah tentu pelayanan perpustakaan yang diberikan pustakawan sudah dianggap berkualitas. Yang kemudian berdampak pada kualitas pelayanan pustakawan di perpustakaan. Berdasarkan hasil dari wawancara yang di lakukan (12 Juni 2021) mengatakan bahwa : "penerapan strategi pustakawan adalah melayani pemustaka cukup tidak baik tidak jelek, karena jarang berkomunikasi"

Menurut Yanti (2018) Layanan berada di garis depan pengembangan 
perpustakaan lebih lanjut. Semakin tinggi jumlah pelayanan yang maksimal, maka semakin tinggi pula jumlah kunjungan ke perpustakaan. Oleh karena itu pustakawan harus memiliki perilaku yang baik dalam menjalankan tugasnya sebagai pengelola perpustakaan untuk dapat memberikan jasa pelayanan informasi kepada pemustaka sehingga nantinya akan berdampak baik pada kunjungan pustakawan di perpustakaan.

2. Jenis pelayanan yang belum tersedia di perpustakaan.

Terdapat beberapa jenis layanan pemustaka yang dilaksanakan perpustakaan yang merupakan layanan atau jasa bagi pengguna yang berkunjung di perpustakaan. Pelayanan perpustakaan akan berdampang dengan minat kunjung pemustaka apabila sistem pelayanan nya yang digunakan tepat dan sesuai dengan kebutuhan yang memberikan layanan informasi kepada pemustaka.

Pelayanan yang belum tersedia di perpustakaan sangat menghambat perkembangan dari perpustakaan tersebut, perpustakaan kini sudah banyak menyediakan akses penelusuran melalui internet, dengan disediakan nya layanan untuk mengakses internet penguna dapat mencari informasi apa saja, baik penelusuran tentang perpustakaan atau penelusuran ilmiah. adanya layanan internet di perpustakaan akan memudahkan pemustaka. Berdasarkan hasil dari wawancara yang di lakukan (12 Juni 2021) mengatakan bahwa : "adapun layanan yang belum terealisasikan yaitu layanan internet belum mempunyai ruangan atau komputer untuk mengakses internet di perpustakaan.”

Menurut Sartini (2016) Pemanfaatan teknologi informasi di perpustakaan pada akhirnya mendukung layanan perpustakaan dalam praktiknya. Upaya lain yaitu mempersingkat waktu untuk memperoleh layanan kolesi dan peminjaman yang lebih cepat dan akurat, perlu di kenalkan dengan layanan perpustakaan yang mulai menggunakan perangkat IT (teknologi informasi).

3. Jenis layanan yang paling berpengaruh di perpustakaan

Jenis layanan yang paling berpengaruh merupakan layanan ruang baca, layanan sirkulasi, layanan referensi, dan layanan akses internet. Tersedianya beberapa jenis layanan perpustakan yang sangat berpengaruh, hal ini bergantung dari tujuan perpustakaan, jenis perpustakaan merupakan keterampilan tiap-tiap perpustakaan yang dapat mengupayakan layanan untuk pemustaka di perpustakaan yang berbagai macam jenis layanan. Berdasarkan hasil dari wawancara yang di lakukan (12 Juni 2021) mengatakan bahwa : "layanan koleksi, layanan rungang tugas akhir, referens, layanan literasi."

Menurut Asmawardah (2018) tergantung pada jenis perpustakaan itu sendiri, perpustakaan menyediakan berbagai jenis layanan kepada pengguna. Namun, konsep layanan perpustakaan semua sama. Artinya, staf dapat memberikan rujukan kepada pengguna untuk mencari informasi tentang bahan pustaka yang sesuai dengan kebutuhan pengguna. Dengan demikian, keterampilan pelayanan pustakawan untuk mempertemukan pemakai (pembaca) dengan informasi (koleksi) yang diinginkan.

\section{Kendala perpustakaan dalam melaksanakan strategi meningkatkan kemampuan pustakawan.}

Menurut hasil wawancara yang dilaksanakan di perpustakaan Institut Agama Islam Negeri Pontianak pennulis menemukan kendala dalam melaksanakan strategi meningkatkan kemampuan 
pustakawan yang dapat diuraikan sebagai berikut.

1. Kemampuan dasar pustakawan beragam

Kemampuan yang dilakukan oleh pustakawan merupakan dasar dari sistem perpustakaan yang tidak seragam dan mencakup beberapa kursus pelatihan untuk pustakawan, pelatihan pustakawan, seperti pendidikan calon pustakawan tingkat ahli (CPTA), dan Pendidikan Ahli Madya Diploma Perpustakaan (D3 Perpustakaan). Dengan jalur inpassing yang dilaksanakan lewat Perpustakaan Nasional. Beberapa lulusan Pendidikan yang berbeda-beda tersebut seperti ada kesulitan dalam hal pengembangan Sumber Daya Manusia. Itulah perlunya perpustakaan dalam menyelengarakan pengembangan pustakawan secara sistematis dan berkesinambungan sehingga dapat meningkatkan kemapuan dasarnya sesuai dengan kebutuhan perpustakaan. Berdasarkan hasil dari wawancara yang di lakukan (18 Agustus 2021) mengatakan bahwa : "Kompetensi SDM berlatar belakang yang berbeda-beda menjadi kendala dalam memberikan tugas-tugas kepada mereka yang mendasari pustakawan belum sepakat sehingga tugas belum bisa dialihkan kepada pustakawan.”

Menurut Nurmarniatun

Peningkatan sumber daya manusia pustakawan perlu adanya strategi, karena keterampilan pustakawan dalam dasar kepustakawanan merupakan kompetensi yang mendasar dikuasai oleh semua pustakawan di perpustakaan perguruan tinggi.

\section{Dana yang terbatas}

Terbatasnya dana merupakan hambatan yang paling utama dalam meningkatkan strategi kemampuan perpustakaan di Perpustakaan IAIN Pontianak yang menyebabkan pustakawan mengalami kesulitan dan hambatan untuk meningkatkan strategi kemampuan pustakawan di perpustakaan secara maksimal. Diantaranya karena minim anggaran pengembangan sumber daya manusia (SDM) di perpustakaan IAIN Pontianak sebagaimana disampaikan. Berdasarkan hasil dari wawancara yang di lakukan (18 Agustus 2021) mengatakan bahwa : "Ada keterbatasan sumber dana untuk pengembangan seperti dana usulan dan keinginan untuk mengikuti diklat, seminar, dll. Ada keterbatasan dana tapi tidak memutuskan harapan, bisa dicari alternatif lain".

Menurut Nurmarniatun (2019) Diantaranya kendala pengembangan SDM oleh internal perpustakaan adalah keterbatasan dana, pastikan kemacetan anggaran tidak menyebabkan masalah pengembangan keterampilan, karena pustakawan harus lebih aktif dalam kursus pelatihan dengan biaya sendiri atau dengan ide mereka sendiri atau dengan tutorial dari internet.

Oleh karena itu, masalah minimnya anggaran dalam pengembangan pustakawan bisa diselesaikan melalui kreativitas pustakawan dalam mengoptimalkan dirinya, seperti dengan mengasah kraktifitas dirinya sendiri.

3.Pustakawan belum menguasai aplikasi dasar sistem informasi

Kemampuan dasar komputer menjadi tolak ukur pustakawan dalam mengembangkan suatu perpustakaan seperti dasar komputer, sistem informasi ini hambatan dalam pelatihan pustakawan. Pesannya, pendidikan TI bagi pustakawan 
perlu di tingkatkan, mengingat TI telah berkembang pesat seperti realita pengguna perpustakaan saat ini. Demikian pula realita pengguna perpustakaan saat ini, khususnya mahasiwa, tidak terlepas dari TI. Itu berarti adalah bagian integral dari kehidupan mereka. Pendapat ini berdasarkakn hasil wawancara yang di lakukan pada (18 Agustus 2021) yang mengatakan bahwa : "Penguasaan atau skill kemampuan komputer keragaman yang berbeda-beda setiap pustakawan seperti contohnya ada yang tidak memahami excel dan masih belum memahami aplikasi-aplikasi

\section{SIMPULAN DAN SARAN}

\section{Simpulan}

Berdasarkan dari hasil penelitian, maka diperoleh kesimpulan yaitu strategi Perpustakaan Institut Agama Islam Negeri Pontianak dalam meningkatkan kemampuan pustakawan yaitu Mengikutsertakan pustakawan pada diklat kepustakawanan. mengikutsertakan pustakawan dalam pelatihan atau seminar/Webinar Nasional, menjadi anggota pada organisasi kepustakawanan baik tingkat daerah provinsi maupun pada organisasi kepustakawanan nasional ikatan pustakawan indonesia (IPI). Pemberian layanan kepada pemustaka yaitu perilaku pustakawan dalam menghadapi pemustaka untuk meningkatkan layanan yang ada di perpustakaan, jenis layanan yang belum tersedia di perpustakaan, dan jenis layanan paling berpengaruh di perpustakaan.

Kendala perpustakaan dalam melaksanakan strategi meningkatkan kemampuan pustakawan yaitu kemampuan dasar pustakawan beragam, dana terbatas dan pustakawan belum menguasai aplikasi dasar sistem informasi. perpustakaan itu menjadi kendala dalam mengikuti pelatihan-pelatihan yang misalkan diselenggarakan oleh perpustakaan lain. Tetapi untuk yang latar belakang Ilmu Perpustakaan menjadi penopang untuk pustakawan yang belum memahami sistem dasar komputer".

Menurut Nurmarniatun (2019) literasi dasar komputer dasar tentu menjadi kendala bagi pendidikan yang diikuti pustakawan. Kegiatan pelatihan perpustakaan hampir pasti dapat mencakup materi teknologi informasiMenurut Komarudin dalam.

\section{Saran}

Berdasarkan hasil penelitian, maka hal yang dapat disarankan yaitu, Diharapkan kepada pengelola perpustakaan IAIN Pontianak untuk dapat meningkatkan strategi kemampuan pustakawan dalam melayani pemustaka. Hal ini untuk meningkatkan kemampuan, pengetahuan dan keterampilan pustakawan dalam menjalankan tugasnya. Diharapkan kepada kepala perpustakaan dapat meningkatkan kinerja pustakawan dengan menerapkan pelayanan yang sesuai dengan keilmuan dalam dunia perpustakaan. Diharapkan kepada pengelola perpustakaan IAIN Pontianak dapat mengatasi kendala-kendala yang ada di perpustakaan dengan pengelola lebih menambah pengetahuan lebih mendalam seperti meningkatkan fasilitas yang dianggap masih kurang di perpustakaan sehingga dapat menangani kendala dalam strategi meningkatkan kemampuan pustakawan dalam melayani pemustaka. 


\section{DAFTAR RUJUKAN}

Asmawardah. (2018). Pelayanan Perpustakaan: Upaya Meningkatkan Mutu Pelayanan Perpustakaan. Diambil kembali dari http://idr.uinantasari.ac.id/10284/q/ PELAYANAN\%20PERPUSTAKA AN.pdf

Darmanto, P. (2020). Manajemen Perpustakaan. Jakarta: Bumi Aksara.

Rahayu, L., K, R, A. (2011). Pelayanan Bahan Pustaka. Jakarta; Universitas Terbuka

Rahayu, L. (2015). Materi Pokok Layanan Perpustakaan. Tangerang Selatan; Universitas Terbuka.

Nurwarniatun. (2019). Pengembangan SDM Pustakawan di Perpustakaan Kediri. Pengembangan SDM Pustakawan di Perpustakaan Kediri. Diambil kembali dari http://download.garuda.ristekdikti.g o.id/article.php?article $=1270523 \& \mathrm{v}$ al $=15723 \&$ title $=$ pengembangan $\% 2$ 0SDM\%20pustakawan\%20di\%20P erpustakaan\%20IAIN\%20Kediri

Qurotianti, A. (2018). Strategi pengembangan sumber daya manusia dalam menerapkan pelayanan prima di perpustakaan perguruan tinggi. Diambil kembali dari

http://repository.umy.ac.id/bitstrea $\mathrm{m} /$ handle/123456789/36376/docum ent.pdf? sequence $=1 \&$ isAllOwed $=y$
Rulyah, S.. (2018). Profesi Pustakawan : Tentang dan Peluang. Vol-34. https://core.ac.uk/download/pdf/26 7825535.pdf

Sartini, L. S. (2016). Mengenal Layanan Perpustakaan . Diambil kembali dari

https:dpkp.ntbprov.go.od/beritamengenal-layanaperpustakaan.html

Yanti, E. (2018). Perilaku Pustakawan Terhadap Pemustaka Dalam meningkatkan Layanan di Perpustakaan Akademi Kebidanan Jakarta Mitra Sejahtera Annisa Kota Jambi. Islam Negeri Sultan Thaha Saifuddin, Adab dan Humaniora. Diambil kembali dari http://repository.uinjambi.ac.id/812 /1/IPT_111117_ELVI_YANTI_IL MU_PERPUSTAKAANcompresse d\%5BI\%5D\%20\%20elvi\%20yanti. pdf 